\title{
OCULAR MANIFESTATIONS OF HIV/AIDS AMONG PATIENTS RECEIVING HIGHLY ACTIVE ANTIRETROVIRAL THERAPY IN A TERTIARY CARE CENTRE
}

\author{
Sanjay Kai ${ }^{1}$, Shiffali Sarngal2 ${ }^{2}$, Aditya Aseem ${ }^{3}$, Sharika Ganjoo ${ }^{4}$ \\ ${ }^{1}$ Assistant Professor, Department of Ophthalmology, Government Medical College, Jammu. \\ ${ }^{2}$ Demonstrator, Department of Forensic Medicine, Government Medical College, Jammu. \\ ${ }^{3}$ Post Graduate, Department of Ophthalmology, Government Medical College, Jammu. \\ ${ }^{4}$ Post Graduate, Department of Ophthalmology, Government Medical College, Jammu.
}

\section{ABSTRACT}

\section{BACKGROUND}

Human Immunodeficiency Virus (HIV) is a retrovirus, which causes Acquired Immune Deficiency Syndrome (AIDS). Since its discovery in 1981, HIV/AIDS has emerged as a global health problem. The ocular manifestations of HIV/AIDS are mostly due to opportunistic infections and neoplasias that accompany the syndrome. In addition, HIV/AIDS also present with orbital and neuroophthalmic manifestations.
AIMS
- To study the prevalence of ocular involvement in HIV/AIDS patients.
- To study the relationship between ocular complications in HIV infection and the degree of immunodeficiency as measured by the CD4+ lymphocyte count.
- To diagnose sight threatening complications in HIV infection and provide appropriate available medical treatment.

\section{SETTINGS AND DESIGN}

Hospital based prospective study.

\section{METHODS AND MATERIALS}

A minimum of 200 cases of HIV infected and AIDS patients undergoing Highly Active Antiretroviral Therapy attending the Outpatient Department of Ophthalmology were selected for the study. Each patient was subjected to detailed history taking regarding the symptoms and duration of the disease. A careful and detailed examination of the eye was undertaken.

\section{STATISTICAL ANALYSIS}

Chi-square test.

\section{RESULTS}

- Majority of the patients belonged to the age group of 31-45 yrs.

- A $49 \%$ of the patients had acquired infection by sexual route, $10 \%$ had acquired perinatally and $40 \%$ denied to reveal the route of acquiring the infection.

- $\quad$ A $91 \%$ had best corrected visual acuity $>6 / 18$.

A $27 \%$ of the patients had ocular manifestations with posterior segment. The most common lesion found was HIV retinopathy found in $9 \%$ of patients, followed by CMV retinitis in $6.5 \%$. "The most common anterior segment manifestation was Anterior uveitis (4\%)."

\section{KEYWORDS}

Ocular Involvement, Complications, CD4+ T-Lymphocyte Count.

HOW TO CITE THIS ARTICLE: Sanjay Kai, Shiffali Sarngal, Aditya Aseem, Sharika Ganjoo. “Ocular Manifestations of HIV/AIDS among Patients Receiving Highly Active Antiretroviral Therapy in a Tertiary Care Centre." Journal of Evolution of Medical and Dental Sciences 2015; Vol. 4, Issue 98, December 07; Page: 16299-16304, DOI: 10.14260/jemds/2015/2405

\section{INTRODUCTION}

Human Immunodeficiency Virus (HIV) is a retrovirus, which causes Acquired Immune Deficiency Syndrome (AIDS) (O’Brien SJ and Goedert JJ, 1996).(1)

Financial or Other, Competing Interest: None.

Submission 17-11-2015, Peer Review 18-11-2015,

Acceptance 30-11-2015, Published 04-12-2015.

Corresponding Author:

Dr. Sanjay Kai,

House No. 39, Canal Road,

Rajinder Nagar,

Jammu and Kashmir.

E-mail: drsanjaykai@gmail.com

DOI:10.14260/jemds/2015/2405
Since its discovery in 1981, HIV/AIDS has emerged as a global health problem. A total of 35 million people are living with HIV with 2.1 million being newly infected in 2013 (UNAIDS World AIDS Day report, 2014).

People living with HIV/AIDS in India are estimated to be 20.89 lakhs with an adult prevalence of $0.27 \%$ (National AIDS Control Organization Annual Report, 2014). India harbours the world's second largest burden of HIV infected population with two Indians becoming HIV infected every minute (Murthy GVS, 2008).(2) The prevalence rate of HIV/AIDS has been reported to be $0.8 \%$ globally.

The CD4+ T lymphocyte is the primary target for HIV infections because of the affinity of the virus for the CD4+ 
surface marker (CD-cluster of differentiation). CD4+ T lymphocytes coordinate a number of important immunologic structures and loss of these result in progressive impairment of the immune response. CD4+ T lymphocyte counts are used to guide clinical and therapeutic management of HIV infected patients.

There are several ways of making a diagnosis of HIV/AIDS. HIV tests available for diagnosis include antibody testing such as Enzyme Immune Assay (Home kits, rapid tests, saliva tests, urine tests, and vaginal secretion), Immunofluorescent Assay and Western Blot. The available antigen tests include p24 antigen and peripheral blood monocyte Polymerase Chain Reaction (PBMC DNA PCR).

Plasma viral load can also be measured using the reverse transcriptase polymerase chain reaction method. This involves amplifying proviral DNA in the laboratory, so that a diagnosis of infection can be made.

Antiretroviral therapy has reduced morbidity and mortality rates in advanced HIV disease in both the developed and developing world.

Introduction of HAART has reduced the risk of mortality, opportunistic infections and improved the quality of life of HIV/AIDS patients. On the contrary, widespread use of HAART tends to increase the prevalence of HIV/AIDS, because survival improves to a greater extent than decline in transmission of HIV infection (Venkatesh KK, et al. 2008).(3)

The ocular manifestations of HIV/AIDS are mostly due to the opportunistic infections and neoplasias that accompany the syndrome. In addition, HIV/AIDS also presents with orbital and neuro-ophthalmic manifestations.

Anterior segment involvement usually results in tumours and external infections while posterior segment involvement usually results in HIV-retinopathy and a number of opportunistic infections of the retina and the choroid.

Early detection of the ocular manifestations of HIV/AIDS is critical since these ocular manifestations may be the primary presentation of the systemic infection (Sahu DK, et al. 1999).(4)

The severity of ophthalmic sequelae of HIV infection increases as immunocompetency decreases, which is measured by CD4+ T cells count (Kempen JH, 2008).(5) It can involve any part of the eye from the adnexa and anterior segment to the posterior segment.

CD4+ T Lymphocyte Count in patients presenting with common HIV-associated disorders involving the eye (Cunningham ET, Jr., et al. 1998).(6)

\begin{tabular}{|c|c|}
\hline CD4+ Count & Disorder \\
\hline$<500$ & Kaposi's sarcoma \\
cells $/ \mathrm{mm}^{3}$ & Lymphoma \\
$<250$ & Tuberculosis \\
cells $/ \mathrm{mm}^{3}$ & Pneumocystis carinii \\
$<100$ & Toxoplasmosis \\
cells $/ \mathrm{mm}^{3}$ & Retinal/Conjunctival microvasculopathy \\
& Cytomegalovirus retinitis \\
& Keratoconjunctivitis sicca \\
& Varicella zoster virus retinitis \\
& Mycobacterium avium complex infection \\
& Cryptococcosis \\
& Microsporidiosis \\
& HIV encephalopathy \\
& Progressive multifocal \\
& leucoencephalopathy \\
\hline
\end{tabular}

The need of the hour is an understanding of ocular sequelae of HIV infection leading to an early diagnosis of AIDS, which along with an early and effective treatment might be able to reduce ocular and general morbidity and mortality in AIDS.

Thus, the present study was undertaken to determine the prevalence of ocular manifestations of HIV/AIDS and its correlation with immunodeficiency. It emphasizes on the need of developing a specific ophthalmic examination for the management of ocular sequelae in the care of HIV infected patients.

\section{METHODS AND MATERIAL}

The data was generated through collection of samples drawn from HIV infected patients attending Outpatient Department of Ophthalmology.

A minimum of 200 cases of HIV infected and AIDS patient undergoing highly active antiretroviral therapy attending the Outpatient Department of Ophthalmology were selected for the study.

Each patient was subjected to detailed history taking regarding the symptoms and duration of the disease. A careful and detailed examination of the eye was undertaken including examination of ocular adnexa and anterior segment.

Examination of posterior segment was done by direct and indirect ophthalmoscopy and +90D biomicroscopy.

Recording of BCVA and intraocular pressure was done.

Routine laboratory investigation like complete hemogram, serum creatinine, blood urea, blood sugar.

CD4+ T lymphocyte count was noted at the start of study and repeated every 6 months thereafter.

Followup of all cases was done every 2 months or more frequently depending on the severity.

\section{STATISTICS}

Chi square test was applied.

\section{RESULTS}

In our study, the mean age of the patients was found to be 39.52 years ranging from 3 years to 78 years with a SD of 16.96 years. Majority of the patients, i.e. 84(42\%) were within the age group of 31-45 years.

The HIV incidence was higher in males as compared to females ( $62 \%$ vs $38 \%$ ). Our study found sexual route as the most common mode of transmission of HIV seen in 98 patients. Twenty patients acquired the infection perinatally and in two patients it could possibly be traced to blood transfusion. Eighty patients denied any of the above routes of transmission. (Table I) and Figure I.

In the present study, ocular manifestations were seen in $54(27 \%)$ patients; 18 patients $(9.0 \%)$ had HIV retinopathy, which was the commonest manifestation. The manifestation wise distribution is given in Table II and Figure II.

In the present study majority of the patients i.e., 118 (59\%) belonged to WHO clinical stage 1 and 2. Eighty two (41\%) patients belonged to WHO clinical stage 3 and 4 . The majority of HIV infected patients with ocular manifestations belonged to stage 3 and 4. (Table III) and Figure III.

Chi-square analysis showed that prevalence of ocular manifestations associated with HIV was significantly higher in patients in clinical stages 3 and 4 . 
In our study the majority of HIV infected patients with ocular manifestations, i.e. $26(68.4 \%)$ had CD4+ T cell counts $<100$ cells $/ \mu \mathrm{l}$. The rest of the patients had CD4+ T cell counts between 100 and 400 cells/ $\mu$ l and only 1 patient (6.25\%) had CD $4+$ T cell count $>400$ cells $/ \mu$ l. (Table IV) and Figure-IV.

Chi-square analysis was done which showed significant correlation $(\mathrm{p}=0.001)$ between ocular manifestations in HIV and lower CD4+ T cell counts.

At the time of presentation, $91 \%$ of the patients had good vision (BCVA 6/6-6/18), 7\% of the patients had low vision (BCVA 6/24-3/60) and 2\% of the patients were blind (BCVA $<3 / 60$ ). (Table $V$ ) and Figure-V.

\section{DISCUSSION}

In the present study the mean age of the participants was 39.52 years, standard deviation (SD) 16.96 years, ranging from 3-78 years. Majority i.e., 84 (42\%) participants were in the age group of 31-45 years; 124 (62\%) patients were males and 76 (38\%) patients were females.

Biswas J, et al. (2000).(7) found the mean age of the participants being 26 years and most patients (76\%) belonged to the age group of 20-40 years. Another study conducted in South India by Sahu DK et al. (1999).(4) reported the mean age as 34 years (range $25-43$ years).

In our study $62 \%$ of the patients were males, $38 \%$ were females. The male-to-female ratio is 1.6:1. Male predominance is consistently higher in most of the studies. In the present study male-to-female ratio was almost equal to the study conducted by Acharya PK et al. (2012).(8) in which male-tofemale ratio was 1.17:1.

The present study shows the most common risk of exposure is sexual 98(49\%) participants. Twenty patients $(10 \%)$ had acquired the infection perinatally and in $2(1 \%)$ patients, the mode of acquiring infection could possibly be traced to blood transfusion. Rest of the $40 \%$ denied revealing the route of infection. Biswas J et al. (2000).(7) have similarly reported that $70 \%$ of the patients had acquired HIV infection by heterosexual.

Shah SU et al. (2009).(9) have reported that the percentage of visual impairment in AIDS patients due to HIV related ocular disease is $6 \%$ including blindness (1\%). Acharya PK et al. (2012).(8) found that out of 553 patients, $481(87 \%)$ patients had a BCVA of $>6 / 18$, whereas 26 patients $(4.7 \%)$ had BCVA less than $3 / 60$. In our study majority, i.e. $182(91 \%)$ had good vision $(>6 / 18)$.

In our study, the ocular manifestations of HIV/AIDS was found in 54(27\%) patients. Lewallen S et al. (1994).(10) in a study of 99 patients with AIDS reported that $26 \%$ of the patients had abnormal ocular findings. Biswas $\mathrm{J}$ et al. (1999).(11) reported ocular lesions in $45.7 \%$ of the HIV infected patients examined at a referral eye center in Chennai.

In the present study, 18(9\%) patients had HIV retinopathy as the most common ocular finding. Of these 18 patients, 12 had cotton wool spots (CWS), i.e. 8 having only CWS and 4 having both CWS and dot haemorrhages; 6 patients had retinal hemorrhages only in the form of flame shaped and dot haemorrhages. No patient had visual impairment attributable to HIV retinopathy.

In the present study, Cytomegalovirus retinitis was found in 13 patients $(6.5 \%)$. It is the second most common ocular finding and the most common ocular opportunistic infection in our series.
Biswas J et al. (1999).(11) in a study have reported CMV retinitis in $17 \%$ of the patients. Jabs DA et al. (2007).(12) observed CMV retinitis as the most frequent ocular finding in $22.7 \%$ of the study participants.

In our study, $4(2 \%)$ patients had neuro-ophthalmic abnormality. They included papilledema in $2(1 \%)$ patients with meningitis and optic neuritis in 2(1\%) patients. Mansour AM (1990).(13) in a study on neuro-ophthalmic findings in acquired immunodeficiency syndrome reported abnormalities in the form of perineuritis, papilledema, papillitis, retrobulbar neuritis, and optic atrophy in about $6 \%$ of the patients.

Other posterior segment manifestations in our study included choroiditis in $2(1 \%)$ patients, vitritis in $2(1 \%)$ patients and retinal detachment in $1(0.5 \%)$ patient. Shah SU et al. (2009).(9) reported immune recovery vitritis in 3\% of the patients of HIV/AIDS. Biswas J et al. (1999).(11) has reported chorioretinitis in $5 \%$ of the patients and relatively higher incidence of retinal detachment occurring in $5 \%$ of patients.

Our study showed comparatively less occurrence of adnexal and anterior segment manifestations as compared to the posterior segment findings in HIV/AIDS. There were no cases of Kaposi's sarcoma in this study, which is in agreement with the similar studies in India and is thought to be due to low seroprevalence of HHV-8 (Causative organism of Kaposi's sarcoma) in our population. In a study by Biswas J et al. (1999).(11) Molluscum contagiosum was observed in $1.4 \%$ of the patients.

Similarly Sudershan S et al. (2013).(14) have found lesser frequency of anterior segment manifestation as compared to posterior segment manifestations with $10 \%$ of patients having anterior segment inflammation.

In our study, $82(41 \%)$ patients belonged to WHO clinical stage 3 and 4 and 118 (59\%) patients belonged to stage 1 and 2; $51.2 \%$ of the patients in WHO clinical stage 3 and 4 had ocular manifestation. Chi-square analysis showed that the prevalence of ophthalmic manifestations associated with HIV was significantly higher in those with WHO clinical stages 3 or 4 ( $\mathrm{p}$ value $<0.001)$.

Jabs DA et al. (2005).(15) have reported that the HIV patients with eye diseases had more advanced immunodeficiency reflected by advanced WHO stage of disease. Our study showed that the prevalence of ocular lesions associated with HIV was significantly higher in patients belonging to WHO clinical stages 3 or 4 and is comparable with other previous studies.

Thus, WHO clinical stage may be an important predictor of the presence of ophthalmic manifestations of HIV.

In our study, the majority of patients with ocular manifestations, i.e. $26(68.4 \%)$ had CD4+ T cell counts $<100$ cells/ $\mu$ l. Rest of the patients had CD4+ T cell count between 100 and 400 cells/ $\mu$ land only 1 patient (6.25\%) had CD $4+T$ cell count $>500$ cells $/ \mu$ l. Chi square analysis of the data revealed $p$ value of $<0.001$, which is highly significant.

Shah SU et al. (2009).(8), in a study have found the prevalence of the ocular manifestations due to HIV/AIDS to be maximum in patients with CD4+ T cell counts $0-100$ cells $/ \mu \mathrm{l}$ than 101-200 cells/ $\mu$ l and the difference was statistically significant.

In our study, we found a significant association between ocular manifestations and lower CD4+ T cell count (0-100 cells $/ \mu \mathrm{l})$, which is in accordance with other previous studies. 


\section{REFERENCES}

1. O'Brien SJ, Goedert JJ. HIV causes AIDS: Koch's postulates fulfilled. Curr Opin Immunol 1996;8:613-8.

2. Murthy GVS. The socioeconomic impact of Human Immunodeficiency Virus/Acquired Immunodeficiency Syndrome in India and its relevance to eye care. Ind J Ophthalmol 2008;56:395-7.

3. Venkatesh KK, Biswas J, Kumarasamy N. Impact of Highly Active Antiretroviral Therapy on ophthalmic manifestations in HIV/AIDS. Ind J Ophthalmol 2008;56:391-3.

4. Sahu DK, Namperumalsamy P, Walimbe P, Rajalakshmi C. Ocular manifestations of HIV infection/AIDS in South Indian patients. Ind J Ophthalmol 1999;47:79-85.

5. Kempen JH. Medical management of Human Immunodeficiency Virus infection. Ind J Ophthalmol 2008;56:385-90.

6. Cunningham ET Jr, Margolis TP. Ocular manifestations of HIV infection. New Engl J Med 1998;339:236-44.

7. Biswas J, Madhavan HN, George AE, Kumarasamy N, Solomon S. Ocular lesions associated with HIV infection in India: A series of 100 consecutive patients evaluated to a reference centre. Am J Ophthalmol 2000;129:9-15.

8. Acharya PK, Venugopal KC, Karimsab DP, Balasubramanya S. Ocular Manifestations in patients with HIV Infection/AIDS who were referred from the ART Centre, Hassan, Karnataka, India. J Clin Diagn Res 2012;6:1756-60.

9. Shah SU, Kerkar SP, Pazare AR. Evaluation of ocular manifestations and blindness in HIV/AIDS patients on HAART in a Tertiary Care Hospital in Western India. Br J Ophthalmol 2009;93:88-90.

\begin{tabular}{|c|c|c|c|}
\hline Ocular Manifestations & $\begin{array}{c}\text { Number } \\
\text { of } \\
\text { Patients } \\
(n=200)\end{array}$ & $\%$ & $\begin{array}{c}95 \% \\
\text { Confidence } \\
\text { Interval }\end{array}$ \\
\hline Absent & 146 & 73.0 & \\
\hline Present & 54 & 27 & $5.7-13.7$ \\
\hline $\begin{array}{ll}\text { 1. } & \text { HIV } \\
& \text { Retinopathy }\end{array}$ & 18 & 9 & $3.8-10.8$ \\
\hline 2. $\quad$ CMV Retinitis & 13 & 6.5 & $2.0-7.6$ \\
\hline $\begin{array}{ll}\text { 3. } & \text { Anterior } \\
\text { Uveitis }\end{array}$ & 8 & 4 & $0.2-3.5$ \\
\hline 4. $\mathrm{HZO}$ & 2 & 1 & $0.2-3.5$ \\
\hline 5. $\quad$ Vitritis & 2 & 1 & $0.2-3.5$ \\
\hline 6. $\quad$ Optic Neuritis & 2 & 1 & $0.2-3.5$ \\
\hline 7. $\quad$ Choroiditis & 2 & 1 & $0.2-3.5$ \\
\hline 8. $\quad$ Papilloedema & 2 & 1 & $0.2-3.5$ \\
\hline 9. $\quad$ Scleritis & 2 & 1 & $0.09-2.7$ \\
\hline $\begin{array}{l}\text { 10. Non-Healing } \\
\text { Corneal Ulcer }\end{array}$ & 1 & 0.5 & $0.09-2.7$ \\
\hline $\begin{array}{l}\text { 11. Orbital } \\
\text { Cellulitis }\end{array}$ & 1 & 0.5 & $0.09-2.7$ \\
\hline $\begin{array}{l}\text { 12. Retinal } \\
\text { Detachment }\end{array}$ & 1 & 0.5 & $0.09-2.7$ \\
\hline \multicolumn{4}{|c|}{$\begin{array}{c}\text { Table II: Prevalence of Ocular } \\
\text { Manifestations in HIV Patients }\end{array}$} \\
\hline
\end{tabular}

*Chi square: 41.36, p-value: 0.001(highly significant)
10. Lewallen S, Kumwenda J, Maher D, Harries AD. Retinal findings in Malawian patients with AIDS. Br J Ophthalmol 1994;78:757-9.

11. Biswas J, Joseph A, Raizada S, Kumamsamy N, Solomon S. Ophthalmic manifestations of Human Immunodeficiency Virus (HIV) infection in India. Ind J Ophthalmol 1999;47:87-93.

12. Jabs DA, Van Natta ML, Holbrook JT, Kempen JH, Meinert CL, Davis MD. Longitudinal study of the ocular complications of AIDS: Ocular diagnoses at enrollment. Ophthalmlogy 2007;114:780-6.

13. Mansour AM. Neuro-ophthalmic findings in Acquired immunodeficiency syndrome. J Clin Neuroophthalmol 1990;10:167-74.

14. Sudharshan S, Kaleemunnisha S, Banu AA, Shrikrishna S, George AE, Babu BR, et al. Ocular lesions in 1,000 consecutive HIV-positive patients in India: a long-term study. J Ophthalmic Inflamm Infect 2013;3:2.

15. Jabs DA, Holbrook JT, Mark L, Van Natta ML, Clark R, Jacobson MA, et al. Risk Factors for Mortality in Patients with AIDS in the Era of Highly Active Antiretroviral Therapy. Ophthalmology 2005;112:771-9.

\begin{tabular}{|c|c|c|}
\hline $\begin{array}{c}\text { Route of } \\
\text { Transmission } \\
\end{array}$ & $\begin{array}{c}\text { Number of } \\
\text { Patients }\end{array}$ & $\%$ \\
\hline Sexual exposure & 98 & 49 \\
\hline Post transfusion & 2 & 1 \\
\hline Vertical transmission & 20 & 10 \\
\hline $\begin{array}{l}\text { Patients who claim no } \\
\text { exposure to any of the } \\
\text { above }\end{array}$ & 80 & 40 \\
\hline Total & 200 & 100.0 \\
\hline \multicolumn{3}{|c|}{ Table I: Routes of Transmission } \\
\hline
\end{tabular}

\begin{tabular}{|c|c|c|c|}
\hline $\begin{array}{c}\text { Clinical } \\
\text { Stage of } \\
\text { HIV/AIDS }\end{array}$ & $\begin{array}{c}\text { Total } \\
\text { Number of } \\
\text { Patients }\end{array}$ & $\begin{array}{c}\text { Patients } \\
\text { with Ocular } \\
\text { Manifestations }\end{array}$ & Percentage \\
\hline 1 & 58 & 3 & 5.1 \\
\hline 2 & 60 & 9 & 15.0 \\
\hline 3 & 46 & 14 & 30.4 \\
\hline 4 & 36 & 28 & 77.7 \\
\hline Total & 200 & 54 & 27.0 \\
\hline \multicolumn{3}{|c|}{ Table III: Ocular Manifestations of AIDS } \\
in Relation to the Clinical Stage of Disease \\
\hline \multicolumn{4}{r}{} \\
\hline
\end{tabular}

\begin{tabular}{|c|c|c|c|c|}
\hline $\begin{array}{c}\text { Sl. } \\
\text { No. }\end{array}$ & $\begin{array}{c}\text { CD4+ T } \\
\text { Cell Count } \\
\text { (cells/ } \boldsymbol{\mu l} \text { ) }\end{array}$ & $\begin{array}{c}\text { Total } \\
\text { no. of } \\
\text { Patients }\end{array}$ & $\begin{array}{c}\text { Patients with } \\
\text { Ocular } \\
\text { Manifestations }\end{array}$ & Percentage \\
\hline 1 & $1-100$ & 38 & 26 & 68.4 \\
\hline 2 & $101-200$ & 44 & 14 & 31.8 \\
\hline 3 & $201-300$ & 60 & 8 & 13.3 \\
\hline 4 & $301-400$ & 42 & 5 & 11.9 \\
\hline 5 & $>401$ & 16 & 1 & 6.25 \\
\hline 6 & Total & 200 & 54 & 27 \\
\hline \multicolumn{4}{|c|}{ Table IV: Correlation of Ocular Manifestations } \\
of AIDS with CD4+ T Cell Count in HIV Infected Patients \\
\hline
\end{tabular}

Chi square: 40.84 , p-value: 0.001(highly significant) 


\begin{tabular}{|c|c|c|}
\hline Visual Acquity & No. of Patients (n= 200) & \% \\
\hline $6 / 6-6 / 18$ & 182 & 91 \\
\hline $6 / 24-3 / 60$ & 14 & 7 \\
\hline$<3 / 60$ & 4 & 2 \\
\hline \multicolumn{3}{|c|}{$\begin{array}{c}\text { Table V: Distribution of Best Corrected Visual Acuity } \\
\text { (BCVA) in HIV Patients at the Time of Presentation. }\end{array}$} \\
\hline
\end{tabular}

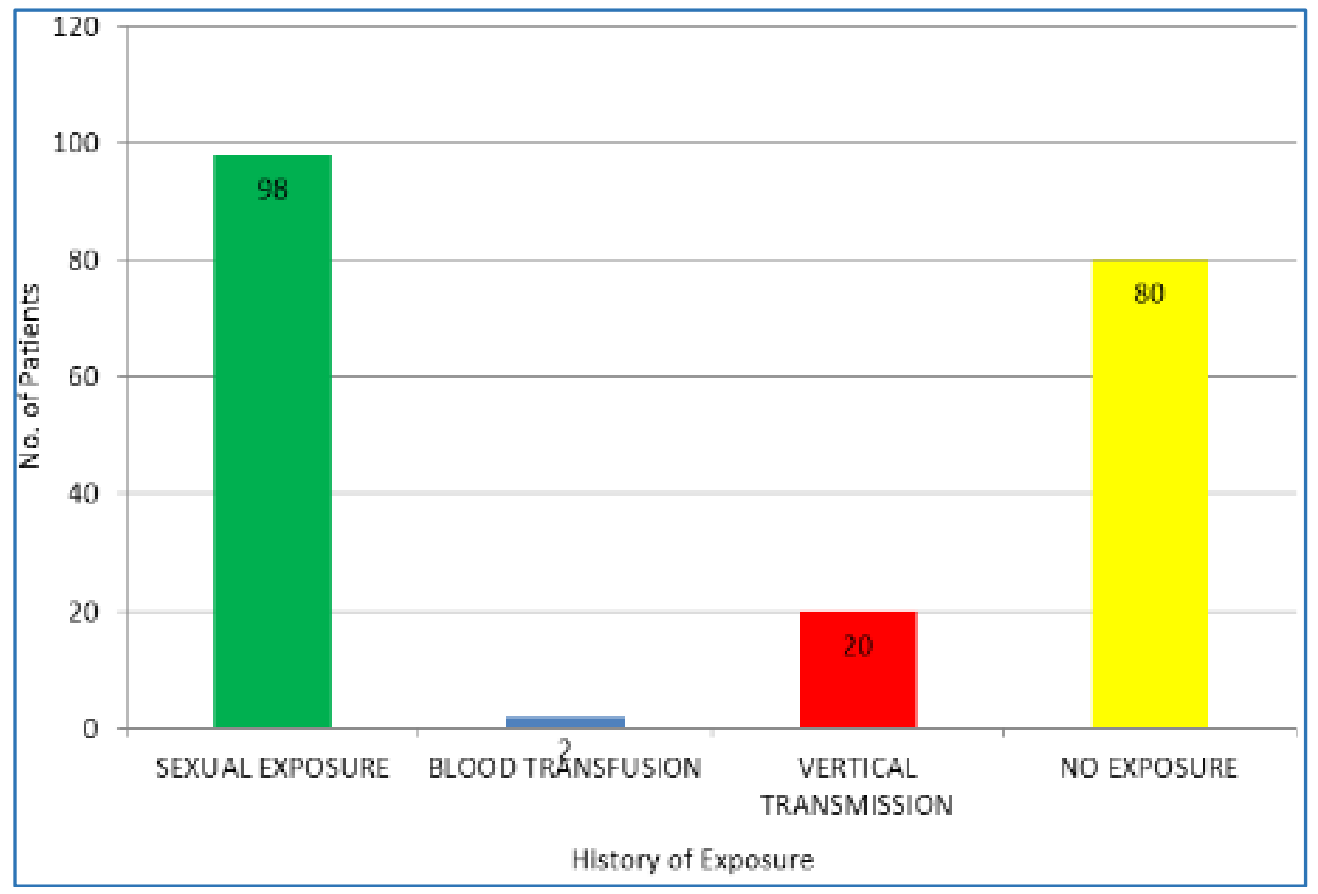

Fig. I: Distribution According to

Routes of Transmission

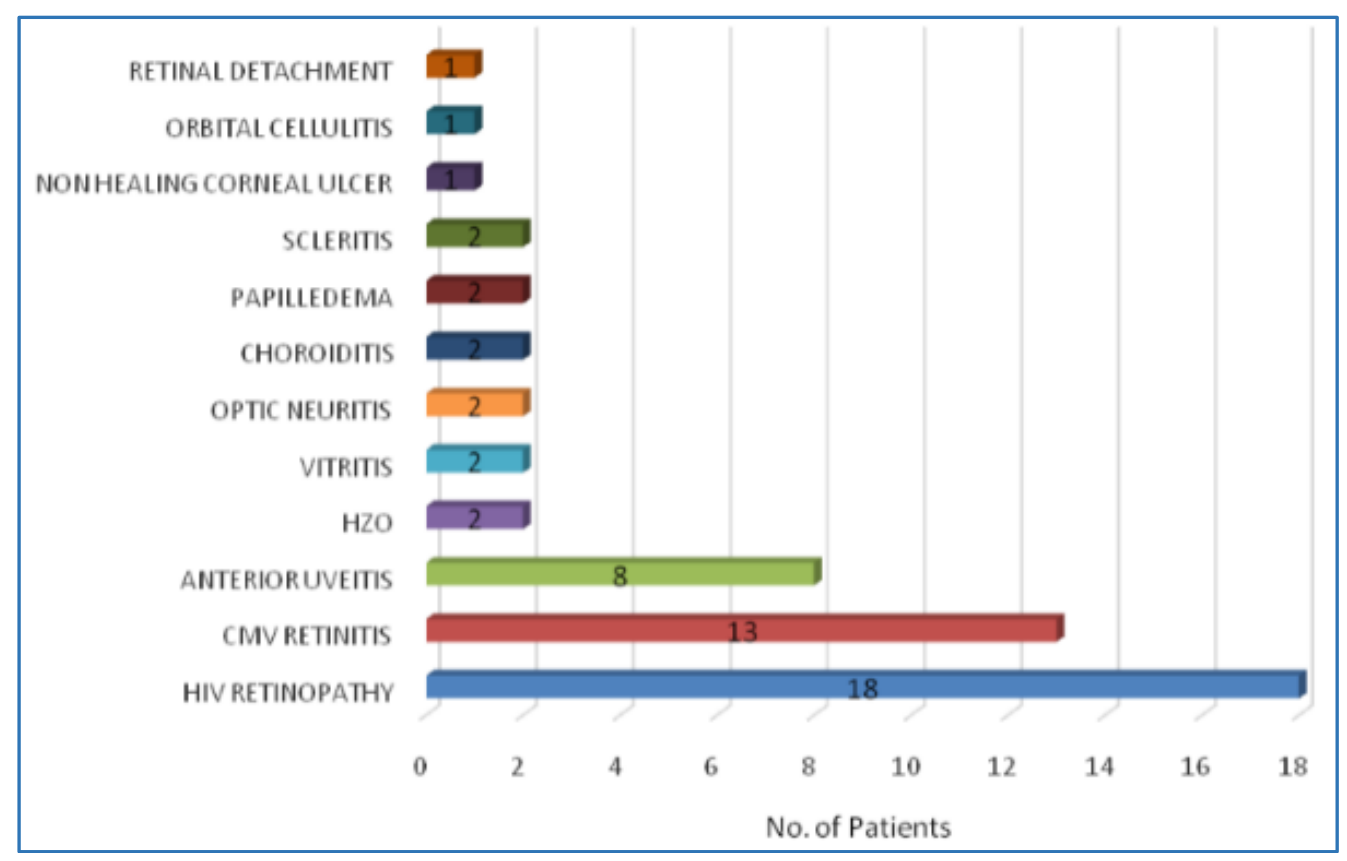

Fig. II: Prevalence of Ocular Manifestations in HIV Patients 


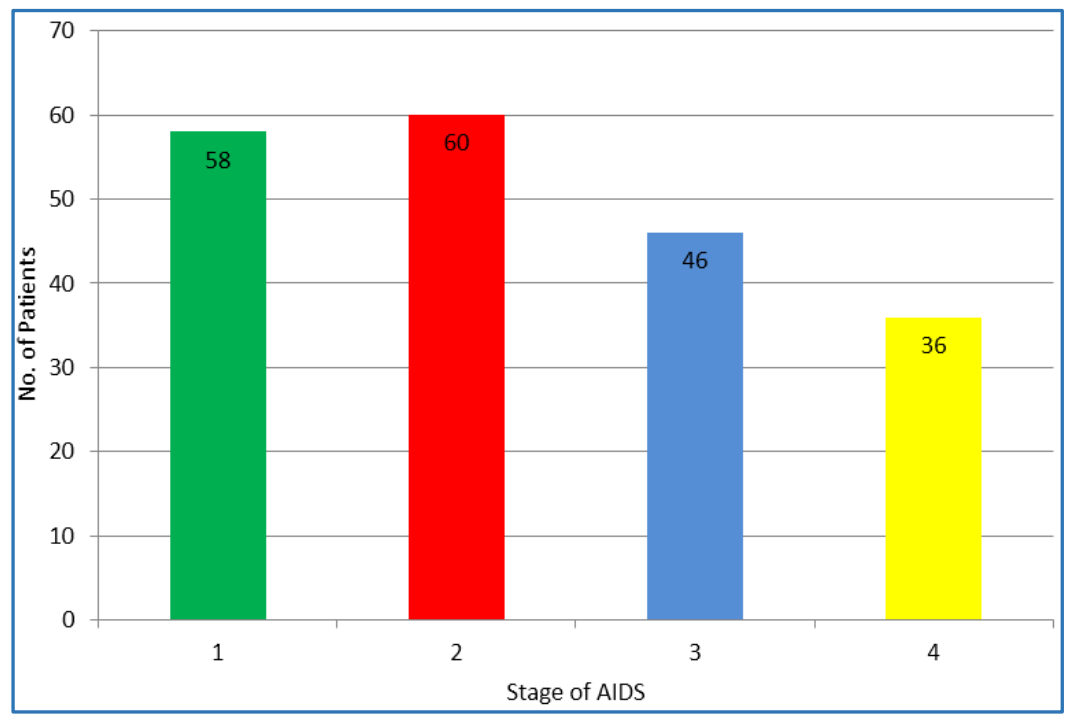

Fig. III: Distribution of Patients According to WHO Staging

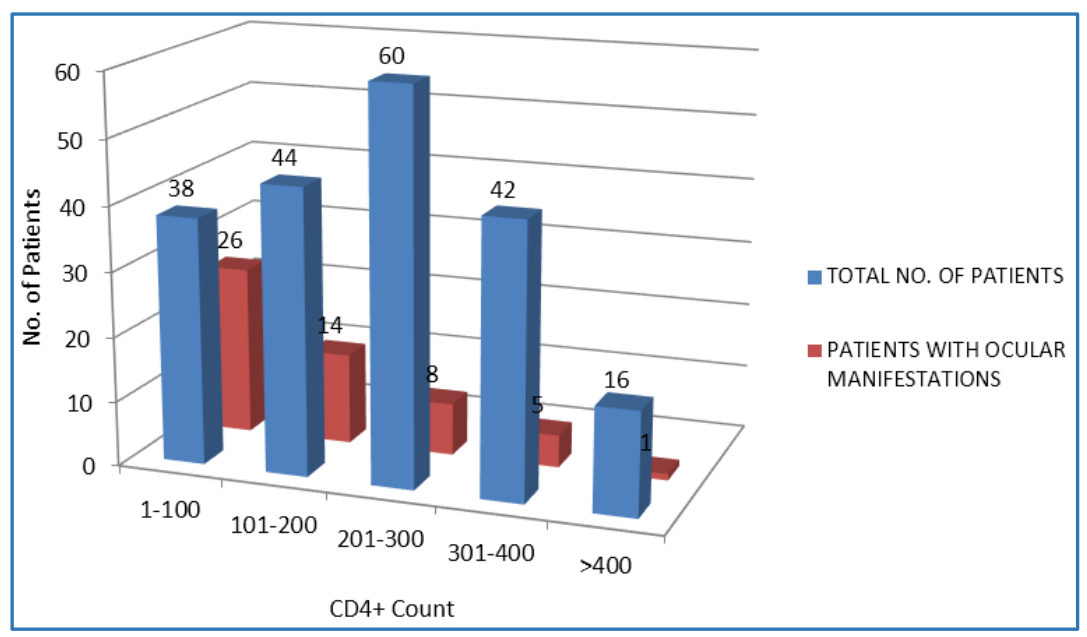

Fig. IV: Distribution of Patients According to CD4+ Count

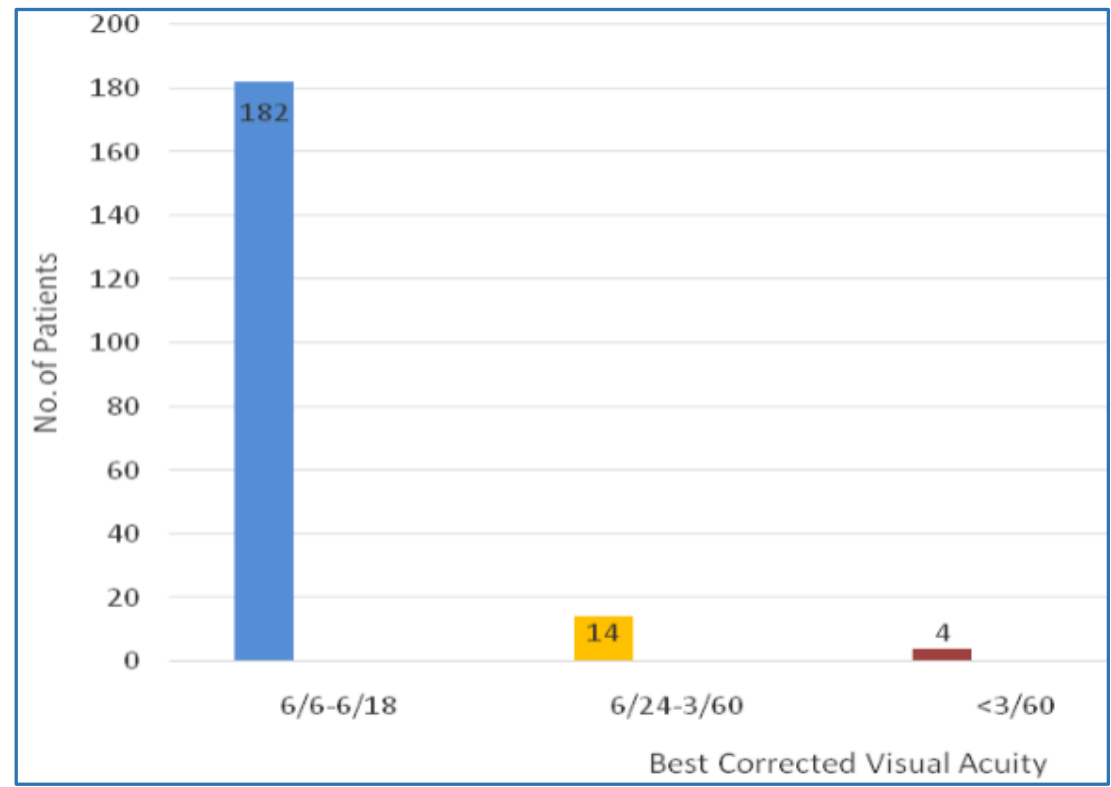

Fig. V: Distribution of Best Corrected Visual Acuity (BCVA) in HIV Patients at the Time of Presentation 